\title{
Ability of Trichoderma harzianum in the Formulation with Carbon Fiber and Silica Nanoparticles to Control Damping-off (Sclerotium rolfsii) on Soybean Plants
}

\author{
Iman Ilahiyyat ${ }^{1}$, Hersanti ${ }^{1 *}$, Luciana Djaya ${ }^{1}$, Sri Hartati ${ }^{1}$ and Ferry Faizal ${ }^{2}$ \\ ${ }^{1}$ Department of Plant Pests and Diseases, Faculty of Agriculture, Universitas Padjadjaran \\ ${ }^{2}$ Nanotechnology and Graphene Research Center, Universitas Padjadjaran \\ Jl. Bandung Raya Sumedang Km. 21 Jatinangor, Indonesia, 45363 \\ *Correspondening author: hersanti09@gmail.com \\ Type of the Paper (Article)
}

Received: 2019-06-30; Accepted: 2019-08-12; Published: 2019-08-30

https://doi.org/10.29253/iptafm.v1i2.34

\begin{abstract}
Sclerotium rolfsii is one of the soil-borne pathogens that cause damping-off and stem rot on soybean plants. One effort to control damping-off, which is environmentally friendly, is by using biological agents. Antagonistic microorganism that has been studied intensively and has a great potential to control soil-borne diseases is Trichoderma harzianum. The objectives of this research were to comprehend the ability of $T$. harzianum in a formulation with carbon fiber 80 mesh and silica nanoparticles (NPs.) and to determine the concentration of silica NPs. in the formulation that suppresses the in vitro growth of $S$. rolfsii and control the damping-off on soybean plants. The experiment was conducted in two phases. The first phase was in vitro experiment, arranged in a completely randomized design with 11 treatments and 3 replications. The second phase was in vivo test by using randomized complete block design, with 11 treatments and 3 replications. The in-vitro test showed that each treatment with $T$. harzianum in the formulation of silica NPs. and carbon fiber 80 mesh in various concentrations was able to suppress the $S$. rolfsii growth by 58.76-80.92\%. The treatment of single $T$. harzianum caused the highest suppression on $S$. rolfsii up to $80.92 \%$. While the results of the in vivo test showed that the highest percentage of damping-off suppression was on the treatment of T. harzianum only, with $60 \%$ suppression.
\end{abstract}

Keywords: soil-borne pathogens, biological agents, stem rot

\section{Introduction}

Soybean \{Glycine max (L.) Merrill\} is one of the crops that have high protein content, which is useful to meet the nutritional needs of humans. Soybean is the main ingredient in tempeh, tofu, soy sauce, soymilk, and soy oil processing. Demands for soybean-based food continue to accelerate as the population growth; therefore, it is necessary to improve soybean farming techniques, including pests and disease management. Soybean plants are often infected by Sclerotium rolfsii, a soil-borne pathogenic fungus that survives in the soil [1]. S. rolfsii affects the plants by causing damping-off on seedlings. Damping-off causes about 75-100\% yield loss in Indonesia [2]. Synthetic fungicides are generally used to control the fungus. The extensive use of synthetic pesticides to control S. rolfsii had harmful impacts on humans and the environment. The use of biological agents could reduce the negative impacts due to the extensive use of synthetic pesticides as well as maintain the sustainability of the environment. One of the antagonistic microbes that have been intensively studied to control soil-borne diseases is Trichoderma harzianum. 
T. harzianum has four mechanisms to suppress plant disease intencity, which are the growth-zone and nutrients competition, antibiosis, and parasitism [3]. Mohiddin et al. (2010) reported that T. harzianum T35 was able to control Fusarium oxysporum by colonizing the rhizosphere and taking more nutrients [4]. T. harzianum is often used to reduce the disease incidence caused by other soil-borne pathogens, such as Sclerotinia sp., Fusarium sp., Pythium sp., Ganoderma sp. and Rigidoporus microporus [5].

Biopesticide can be formulated with other materials as carriers and enrichment. The formulation may be in the form of a solid, powder, or suspension mixture. Some of the carriers had been widely used in many distinctive formulations, e.g., water, oil, and talcum. Carrier material serves as the microbe encapsulation that maintains the microbe viability and survival, as well as keeps the microbes from extreme environments in storage condition and provides a source of nutrients after site application [6].

The carbon fiber used in the experiment was 80 mesh of graphene $(0.177 \mathrm{~mm})$. This material is commonly used as a composite material because it has a rigid structure and is not easily damaged in heat. Besides, carbon fiber also has a large surface for agents and biopesticides to attach in a formulation [7]. Carbon fiber has the potential to be used as a carrier since it could be a site for the antagonists to adhere, as well as nano-sized minerals, such as $\mathrm{Si}, \mathrm{Zn}$, and $\mathrm{Ti}$, that added to the biopesticide formulation as fertilizers [8].

\section{Materials and Methods}

\subsection{Place and Time}

The in vitro experiment was carried at the Laboratory of Phytopathology, Department of Plant Pests and Diseases, Faculty of Agriculture, Universitas Padjadjaran from February to July 2018. The in vivo experiment was carried out at Ciparanje experimental field of Faculty of Agriculture, Universitas Padjadjaran, Jatinangor.

\subsection{Tools and materials}

Tools used in the experiments included Petri dish, tube flasks, test tubes, autoclave, oven, laminar airflow, micropipettes, cork borers, L shape rods, lighters, test tube racks, microwave oven, Schott bottles, analytical scale, $1 \mathrm{ml}$ and $0.1 \mathrm{ml}$ pipette tips, vortex mixer, oven, bunsen flame, sprayer, shaker, hemacytometer, beaker glasses, microscopes, plastic bottles, scissors, test tubes, cameras, and stationeries.

Materials used included: isolate of T. harzianum, isolate of $S$. rolfsii from infected soybean plants, plastic seals, growth media box $\left(40 \times 50 \mathrm{~cm}^{2}\right)$, silica nanoparticles (Si NPs., $100 \mathrm{~nm}$ ) and graphite (C) 80 mesh $(0.177 \mathrm{~mm})$ prepared by Nanotechnology and Graphene Research Center (Print-G) Universitas Padjadjaran, Potato Dextrose Agar, sterile distilled water, cling wrap, aluminum foil, water, filter paper, cotton, alcohol 70\%, spiritus, soil, Anjasmoro soybean seeds, cow manure, and rice.

\subsection{Methods}

The in-vitro experiment was arranged in the completely randomized design consisted of 11 treatments and 3 replications. The treatments were $T$. harzianum $+5 \%$ carbon fiber, $T$. harzianum $+0.5 \%$ silica NPs., $T$. harzianum $+1 \%$ silica NPs., $T$. harzianum $+3 \%$ silica NPs., $T$. harzianum $+5 \%$ silica NPs., T. harzianum $+0.5 \%$ silica NPs. $+5 \%$. carbon fiber, . harzianum $+1 \%$ silica NPs $+5 \%$ carbon fiber, T. harzianum $+3 \%$ silica NPs $+5 \%$ carbon fiber, T. harzianum $+5 \%$ silica NPs. $+5 \%$ carbon fiber, T. harzianum and control (only sterile distilled water). The in vivo experiment was arranged in the randomized block design with the same 11 treatments and 3 replicates.

\subsubsection{Isolates preparation}

S. rolfsii were prepared by culturing on PDA for seven days incubation. The activity was performed aseptically in laminar airflow. For the in vivo experiment, $S$. rolfsii was mass cultured on rice medium. The rice was soaked for twelve hours, and then it was put into heat-resistant plastic bags, $100 \mathrm{~g} / \mathrm{bag}$, and autoclaved at $121^{\circ} \mathrm{C}$ for 15 minutes. Each rice-medium bag was inoculated with five pieces of $S$. rolfsii inoculum on agar medium ( $5 \mathrm{~mm}$ in diameter/piece) and incubated for seven days at $26^{\circ} \mathrm{C}$. Gradually, 
colonies of $S$. rolfsii appeared in white-silky structures. Then the culture of $S$. rolfsii in rice-medium was ready to use.

For the vitro experiment, T. harzianum was cultured on PDA, and incubated for seven days. The spores were collected by adding $10 \mathrm{~mL}$ of distilled water into the Petri dish and carefully scraped. The density of spores was measured by using a hemocytometer. The spore density used was $8.30 \times 10^{8}$ conidia/mL. To test the antagonism, T. harzianum and S. rolfsii were dual cultured on PDA. The inhibition of the $T$. harzianum against $S$. rolfsii was calculated using the following formula:

$$
I=\frac{R 1-R 2}{R 1} X 100 \%
$$

I $\quad=$ Inhibition

R1 = Radius of $S$. rolfsii colony on the opposite direction of $T$. harzianum colony

R2 = Radius of $S$. rolfsii colony towards the center of T. harzianum colony

\subsubsection{Parasitism test}

Parasitism test was conducted by placing mycelia of T. harzianum at each treatment on object-glass, then S. rolfsii was placed on the same object-glass. S. rolfsii mycelia were observed by using a microscope at 400 times magnification.

\subsubsection{Viability test}

The viability test of $T$. harzianum in the formulation with carbon fiber and silica NPs was carried out by dripping formulations that had been incubated for 24 hours on $0.1 \mathrm{~mL}$ PDA media in a petri dish. Then apply using $\mathrm{L}$ stem. Observation of the number of colonies grown is done three days after incubation.

\subsubsection{Incidence of disease}

The incidence of disease was calculated using the equation as follow:

Information:

$$
\mathrm{KP}=\frac{n}{\mathrm{~N}} \times 100 \%
$$

$\mathrm{KP}=$ Disease Incidence

$n=$ number of diseased plants

$\mathrm{N}=$ total number of plants observed

\subsubsection{Damping-off}

Damping-off suppression on soybean plants was calculated using the formula:

Information:

$$
\mathrm{Ps}=\frac{\mathrm{K}-\mathrm{T}}{\mathrm{K}} \times 100 \%
$$

Ps = disease suppression (\%)

$\mathrm{K}=$ average of the disease incidence on control.

$\mathrm{T}=$ disease incidence on treatments.

\subsubsection{Plant Growth}

Plant growth observed were plant height $(\mathrm{cm})$, measured from the base to the tip, and number of leaves at 7 DAT, 14 DAT, 21 DAT and 28 DAT.

\subsubsection{Colonization of $\mathrm{T}$. harzianum on planting medium}

Colonization of $T$. harzianum on the planting medium was measured by taking $10 \mathrm{~g}$ of soil on each treatment, around the stem of soybean plants. The soil sample on each treatment was suspended in sterile distilled water and diluted to $10^{-2}$ and spread inoculated on PDA, and then incubated for 48 hours. After two days of incubation, the number of fungal colonies was counted. 


\subsubsection{Contact angle}

The contact angle of the treatments on the surface of soybean seed was measured by using Contact plugin ImageJ with Angle. By specifying a 2 point limit first droplet with the surface of the preparations, and added 5 points barrier that surrounds the droplet as the droplet, the ImageJ application will automatically calculate the left and right angles $\theta$ of droplets formed by surface preparation.

\section{Results and Discussion}

\subsection{In vitro antagonism between T. harzianum in the formulation of carbon fiber and silica NPs. against $S$. rolfsii}

The results showed the potency of T. harzianum in the formulation of carbon fiber and silica NPs. as antagonist of $S$. rolfsii. This was indicated by the inhibition of the growth of $S$. rolfsii by $T$. harzianum, which ranged between 58.76 to $80.92 \%$ (Table 1). T. harzianum suppressed the radial growth of S. rolfsii on PDA, because T. harzianum had the ability to grow and colonize the medium faster. Trichoderma spp., the soil saprophytic fungi, are also parasites and can naturally affect many other fungi. Trichoderma spp. in general, have a mycoparasitic mechanism and act as aggressive competitors [3]. Based on the results of the antagonism test, T. harzianum in all formulation of carbon fiber and silica NPs. suppressed the growth of $S$. rolfsii in vitro (Table 1)

Table 1. Inhibition of S. rolfsii growth by T. harzianum in the formulation with carbon fiber and silica NPs.

\begin{tabular}{|c|c|c|c|c|}
\hline \multirow{2}{*}{ Treatments } & \multicolumn{4}{|c|}{ Inhibition* (\%) on day: } \\
\hline & 1 & 2 & 3 & 4 \\
\hline A $($ T. harzianum $+5 \% C)$ & 0 & $60.23 \mathrm{ab}$ & $66.28 \mathrm{ab}$ & $64.52 \mathrm{bc}$ \\
\hline $\mathrm{B}(T$. harzianum $+0.5 \% \mathrm{Si})$ & 0 & $57.06 \mathrm{ab}$ & $72.83 \mathrm{ab}$ & $69.84 \mathrm{abc}$ \\
\hline $\mathrm{C}($ T. harzianum $+1 \% \mathrm{Si})$ & 0 & $60.75 \mathrm{ab}$ & $71.28 \mathrm{ab}$ & $71.53 \mathrm{ab}$ \\
\hline $\mathrm{D}($ T. harzianum $+3 \% \mathrm{Si})$ & 0 & $52.90 \mathrm{~b}$ & $70.34 \mathrm{ab}$ & $67.71 \mathrm{bc}$ \\
\hline $\mathrm{E}(T$. harzianum $+5 \% \mathrm{Si})$ & 0 & $55.17 \mathrm{~b}$ & $61.40 \mathrm{~b}$ & $64.31 \mathrm{bc}$ \\
\hline $\mathrm{F}($ T. harzianum $+0.5 \% \mathrm{Si}+5 \% \mathrm{C})$ & 0 & $63.24 \mathrm{ab}$ & $65.14 \mathrm{~b}$ & $65.24 \mathrm{bc}$ \\
\hline $\mathrm{G}(\mathrm{T}$. harzianum $+1 \% \mathrm{Si}+5 \% \mathrm{C})$ & 0 & $59.79 \mathrm{ab}$ & $60.76 \mathrm{~b}$ & $58.76 \mathrm{c}$ \\
\hline $\mathrm{H}(\mathrm{T}$. harzianum $+3 \% \mathrm{Si}+5 \% \mathrm{C})$ & 0 & $61.23 \mathrm{ab}$ & $68.24 \mathrm{ab}$ & $68.75 \mathrm{bc}$ \\
\hline I (T. harzianum + 5\% Si +5\% C) & 0 & $55.46 \mathrm{~b}$ & $61.91 \mathrm{~b}$ & $61.37 \mathrm{bc}$ \\
\hline J (T. harzianum $)$ & 0 & $72.29 \mathrm{a}$ & 80.39 a & $80.92 \mathrm{a}$ \\
\hline $\mathrm{K}$ (Control) & 0 & $0 \mathrm{c}$ & $0 \mathrm{c}$ & $0 \mathrm{~d}$ \\
\hline
\end{tabular}

*Numbers followed by the same letter within a column are not significantly different according to Duncan's multiple range test (5\%).

The results of in-vitro antagonism test showed that each treatment was able to inhibit the growth of $S$. rolfsii on days 2, 3 and 4. On day 2, J treatment (T. harzianum) caused the highest inhibition $(72.29 \%)$, which was not significantly different to A treatment (T. harzianum $+5 \% \mathrm{C})$, B (T. harzianum $+0.5 \% \mathrm{Si})$, $\mathrm{C}(T$. harzianum $+1 \% \mathrm{Si}), \mathrm{F}(\mathrm{T}$. harzianum $+0.5 \% \mathrm{Si}+5 \% \mathrm{C})$, G (T. harzianum $+1 \% \mathrm{Si}+5 \% \mathrm{C})$ and $\mathrm{H}$ (T. harzianum $+3 \% \mathrm{Si}+5 \% \mathrm{C})$. Day 3, the highest inhibition on treatment A (T. harzianum) was 80.39, and not significantly different to A treatment (T. harzianum $+5 \% \mathrm{C})$, B $(T$. harzianum $+0.5 \% \mathrm{Si})$, $\mathrm{C}($ T. harzianum $+1 \% \mathrm{Si}), \mathrm{D}($ T. harzianum $+3 \% \mathrm{Si})$, and $\mathrm{H}($ T. harzianum $+3 \% \mathrm{Si}+5 \% \mathrm{C})$. Like wise the observation on day 4, treatment J (T. harzianum) caused the highest inhibition (80.92\%), which was not significantly different to treatment B $(T$. harzianum $+0.5 \% \mathrm{Si})$ and C $(T$. harzianum $+1 \% \mathrm{Si})$. Dendan (2015), reported that T. harzianum caused the highest inhibition (74\%) on the colonies growth of Ganoderma sp. compared with Trichoderma viridae and Trichoderma pseudokoningii [9]. The inhibition occured through the mechanism of antagonism, that marked in the presence of zones of inhibition. 
T. harzianum is one of the microbial antagonists that are widely used as biocontrol agents of soilborne pathogens. Based on the above observations, the mechanism of T. harzianum in suppressing the development of $S$. rolfsii was due to competition in growing space and nutrients. This was consistent with the results of Chet et al. (1979) [10]. T. harzianum was able to attack and take control of Rhizoctonia solani mycelium growing space. While Howell (2003) reported that T. harzianum degraded the cell wall of the host, mainly due to the chitinase, glucanase, and protease activities [11].

Fadillah (2017) reported that the addition of the mixture of silica NPs. $0.5 \%, 1 \%, 3 \%$ and $5 \%$ did not reduce the viability of Pseudomonas fluorescens. P. fluorescens in the formulation with 5\% Silica NPs [12]. 5\% carbon fiber could still suppress the in vitro growth of Ralstonia solanacearum compared to control, with the inhibition of $85 \%$. Rismaniar (2017) reported that 3\% silica NPs. + carbon fiber formulation was best for the viability of PGPR Bacillus subtilis. B. subtilis in the formulation of carbon fiber and 5\% silica NPs. caused the highest suppression on the in vitro growth of $R$. solanacearum; the inhibition zone was $6.69 \mathrm{~mm}$ [13].

\subsection{Parasitism of T. harzianum in the Formulation of Carbon Fiber and Silica NPs. on S. rolfsii in vitro}

The mechanism of parasitism is an interesting phenomenon that plays an essential role in the process of biological control. Trichoderma sp. has this mechanism together with other mechanisms of competition and antibiosis. Trichoderma spp. have been tested on several plant pathogens, such as Ganoderma sp. [5]. Parasitism of T. harzianum in the formulation with carbon fiber and silica NPs. on $S$. rolfsii in vitro was presented in Fig. 1.
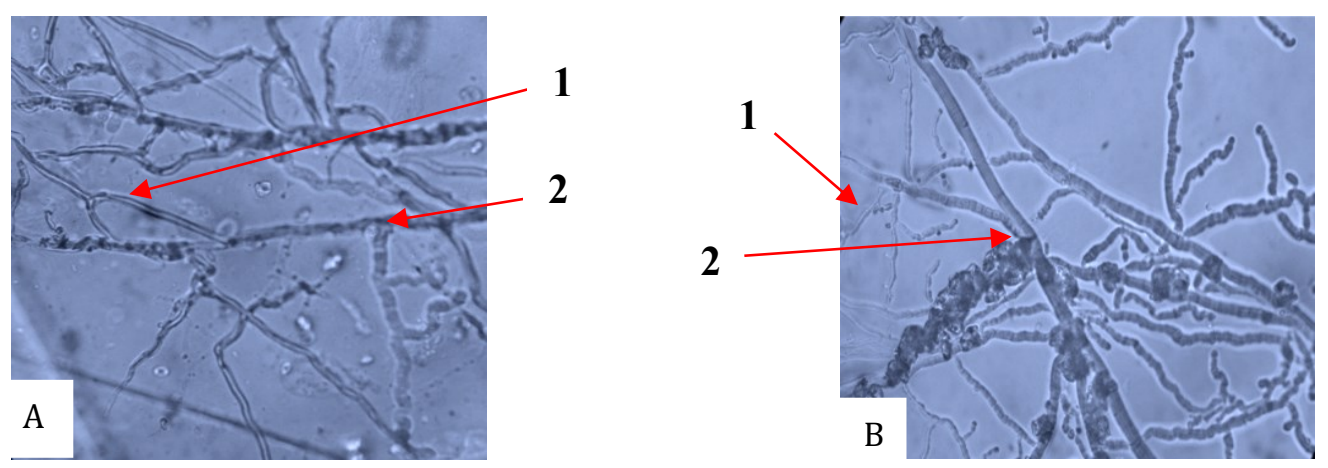

Figure 1. Parasitism of T. harzianum in the formulation with carbon fiber and silica NPs. on $S$. rolfsii. A) Treatment with T. harzianum + silica NPs. 0.5\%. B) Treatment with T. harzianum. 1) Hyphae of T. harzianum. 2) Hyphae of $S$. rolfsii. 400 times magnification

It was observed that $T$. harzianum hyphae was kept growing so that the hyphae of $S$. rolfsii were stunted. As stated by Baker and Cook (1982), generally, the antagonistic mechanisms of Trichoderma spp. in suppressing plant pathogens are parasitism and aggressive competition [3]. Initially, the hyphae of Trichoderma spp. grow longer, then twist and penetrate the pathogenic fungal hyphae as the host so that the host hyphae suffer vacuolation, lysis, and eventually destroyed. According to Widyastuti et al. (1998), Trichoderma spp. penetrated the host cell wall with the aid of cell wall degrading enzymes, such as chitinase, glucanase, and protease then used the contents of the host hyphae as a food source [5]. At the time of twisting and producing enzymes to penetrate the host cell wall, Trichoderma sp. also produces antibiotics such as gliotoxin and viridian. T. harzianum can effectively suppress the growth of plant pathogenic Ganoderma pilippii isolated from a wide variety of trees [14].

\subsection{Viability Test of T. harzianum in the Formulation with Carbon Fiber and Silica NPs.}

In this study, viability was concerned with the ability of T. harzianum to stay alive in the formulation with carbon fiber and silica NPs. that could be seen from the number of spores in the formulation that still grew compared to control in distilled water. Results of the viability test are presented in Table 2 . 
Table 2. Viability of T. harzianum in the formulation with carbon fiber and silica NPs.

\begin{tabular}{|c|c|}
\hline Treatment & $\begin{array}{c}\text { Number of } T \text {. harzianum } \\
\text { colonies (cfu / mL) }\end{array}$ \\
\hline $\mathrm{A}(\mathrm{T}$. harzianum $+5 \% \mathrm{C})$ & $6,49 \times 10^{2} \mathrm{~cd}$ \\
\hline B (T. harzianum $+0,5 \% \mathrm{Si})$ & $6,71 \times 10^{2} \mathrm{~b}$ \\
\hline $\mathrm{C}(\mathrm{T}$. harzianum $+1 \% \mathrm{Si})$ & $6,80 \times 10^{2} \mathrm{~b}$ \\
\hline $\mathrm{D}(\mathrm{T}$. harzianum $+3 \% \mathrm{Si})$ & $6,62 \times 10^{2} \mathrm{cb}$ \\
\hline $\mathrm{E}(\mathrm{T}$. harzianum $+5 \% \mathrm{Si})$ & $6,51 \times 10^{2} \mathrm{~cd}$ \\
\hline $\mathrm{F}(\mathrm{T}$. harzianum $+0,5 \% \mathrm{Si}+5 \% \mathrm{C})$ & $6,39 \times 10^{2} \mathrm{de}$ \\
\hline $\mathrm{G}(\mathrm{T}$. harzianum $+1 \% \mathrm{Si}+5 \% \mathrm{C})$ & $6,33 \times 10^{2} \mathrm{de}$ \\
\hline $\mathrm{H}(\mathrm{T}$. harzianum $+3 \% \mathrm{Si}+5 \% \mathrm{C})$ & $6,50 \times 10^{2} \mathrm{~cd}$ \\
\hline I (T. harzianum $+5 \% \mathrm{Si}+5 \% \mathrm{C})$ & $6,24 \times 10^{2} \mathrm{e}$ \\
\hline $\mathrm{J}($ T. harzianum $)$ & $7,15 \times 10^{2} \mathrm{a}$ \\
\hline
\end{tabular}

$\mathrm{Si}=$ Silica NPs, C = carbon fiber. Numbers followed by the same letter within a column are not significantly different according to Duncan's multiple range test (5\%).

Based on observations of T. harzianum fungi viability in carbon fiber formulations and silica NPs showed that treatment J ( $T$. harzianum) was the treatment which had the highest number of colonies of $7.15 \times 10^{2} \mathrm{cfu} / \mathrm{mL}$ and treatment I ( T. harzianum $\left.+5 \% \mathrm{Si}+5 \% \mathrm{C}\right)$ is the treatment that has the lowest number of fungal colonies with a colony number of $6.24 \times 10^{2} \mathrm{cfu} / \mathrm{mL}$. The addition of carbon fiber and silica NPs influenced the viability of $T$. harzianum fungi. This is presumably because the addition of carbon fibers and silica NPs affects the $\mathrm{pH}$ of the formulation, which decreases the viability of $T$. harzianum. There is a difference between bacteria and fungi (Pseudomonas fluorescens with $T$. harzianum) where Djaya et al. (2017), reported that the addition of 80 mesh carbon fiber with a concentration of $5 \%$ and $5 \%$ silica NPs could maintain the viability of P. fluorescence [15].

\subsection{Effect of T. harzianum in the Formulation with Carbon Fiber and Silica NPs. on Damping Off Disease incidence}

T. harzianum colonizes the rhizosphere and has an antagonistic effect on the soil-borne pathogens. Its mechanisms of antagonism are competing for space, mycoparasitism, and antibiosis. T. harzianum has antagonism properties against various pathogens that cause disease in plants such as Phytophthora, Pythium and Botrytis [16].

Table 4 shows that low disease incidence at 7 days after transplanting (DAT) was $26.67 \%$ on treatment J (T. harzianum). The highest disease incidence, 65\%, was caused by treatments $\mathrm{F}(T$. harzianum $+0.5 \% \mathrm{Si}+5 \% \mathrm{C})$ and $\mathrm{G}(\mathrm{T}$. harzianum $+1 \% \mathrm{Si}+5 \% \mathrm{C})$. The lowest disease incidence on 14 DAT, 26.67\%, was also caused by treatment J (T. harzianum); and the highest were caused by treatments $\mathrm{F}($ T. harzianum $+0.5 \% \mathrm{Si}+5 \% \mathrm{C})$ and $\mathrm{G}(\mathrm{T}$. harzianum $+1 \% \mathrm{Si}+5 \% \mathrm{C}), 66.67 \%$. On $21 \mathrm{DAT}$, the lowest disease incidence occured on treatment J (T. harzianum) also, and still $26.67 \%$; the highest, $66.67 \%$, were on treatments F (T. harzianum $+0.5 \% \mathrm{Si}+5 \% \mathrm{C}), \mathrm{G}($ T. harzianum $+1 \% \mathrm{Si}+5 \% \mathrm{C}$ ), and $\mathrm{K}$ (control). The same lowest disease incidence, $26.67 \%$, at 28 DAT occurred also on treatment J ( T. harzianum); The same highest, $66.67 \%$, were on treatments F (T. harzianum $+0.5 \% \mathrm{Si}+5 \% \mathrm{C}), \mathrm{G}(\mathrm{T}$. harzianum $+1 \% \mathrm{Si}+5 \%$ $\mathrm{C}$ ), and $\mathrm{K}$ (control). Therefore, the highest disease inhibition was caused by treatment J (T. harzianum), $60 \%$. This was in line with the results of in vitro antagonism test and the contact angle on soybean seed. The in vitro test showed that application of single T. hazianum (not formulated) suppressed the growth of pathogenic $S$. rolfsii colonies by $80.92 \%$, which was not significantly different from treatment of $T$. hazianum formulated with $5 \%$ of carbon fiber and silica NPs. (Table 1). The contact angle also demonstrated the effectiveness of treatment $\mathrm{D}(T$. harzianum $+3 \% \mathrm{Si}$ ) and $\mathrm{J}$ (T. harzianum) in the ability to stick to the seed surface, they were $52.3^{\circ}$ and $56.25^{\circ}$ respectively. Singh (2010) reported that the 
addition of silica NPs. to $5000 \mathrm{ppm}$ can inhibit the growth of microbes [17]. However, silica NPs. did not affect the PGPR such as P. fluorescens. Silica NPs. improved the PGPR population in the soil. Therefore, silica NPs. was used as one of the additional material both as fertilizer and pesticide in order to improve the quality of the crop [18].

Table 4. Effect of T. harzianum in the formulation with carbon fiber and silica NPs. on the damping-off incidence on soybean.

\begin{tabular}{lccccc}
\hline \multirow{2}{*}{ Treatment } & \multicolumn{3}{c}{ Disease incidence (\%) on **** } & Inhibition \\
\cline { 2 - 5 } & 7 DAT*** & 14 DAT & 21 DAT & 28 DAT & on 28 DAT \\
\hline A (T. harzianum + 5\% C*) & $55.00 \mathrm{abc}$ & $60.00 \mathrm{abc}$ & $60.00 \mathrm{abc}$ & $61.67 \mathrm{ab}$ & 7.50 \\
B (T. harzianum + 0.5\% Si**) & $46.67 \mathrm{~cd}$ & $50.00 \mathrm{~cd}$ & $50.00 \mathrm{~cd}$ & $50.00 \mathrm{~cd}$ & 25.00 \\
C (T. harzianum + 1\% Si) & $40.00 \mathrm{~d}$ & $41.67 \mathrm{~d}$ & $41.67 \mathrm{~d}$ & $41.67 \mathrm{~d}$ & 37.50 \\
D (T. harzianum + 3\% Si) & $63.33 \mathrm{ab}$ & $63.33 \mathrm{ab}$ & $63.33 \mathrm{ab}$ & $66.67 \mathrm{a}$ & 0,00 \\
E (T. harzianum + 5\% Si) & $51.67 \mathrm{bc}$ & $53.33 \mathrm{bc}$ & $53.33 \mathrm{bc}$ & $53.33 \mathrm{bc}$ & 20.00 \\
F (T. harzianum + 0.5\% Si + 5\% C) & $65.00 \mathrm{a}$ & $66.67 \mathrm{a}$ & $66.67 \mathrm{a}$ & $66.67 \mathrm{a}$ & 0,00 \\
G (T. harzianum + 1\% Si + 5\% C) & $65.00 \mathrm{a}$ & $66.67 \mathrm{a}$ & $66.67 \mathrm{a}$ & $66.67 \mathrm{a}$ & 0,00 \\
H (T. harzianum + 3\% Si + 5\% C) & $55.00 \mathrm{abc}$ & $56.67 \mathrm{abc}$ & $56.67 \mathrm{abc}$ & $56.67 \mathrm{abc}$ & 15,00 \\
I (T. harzianum + 5\% 5\% Si + C) & $60.00 \mathrm{ab}$ & $60.00 \mathrm{abc}$ & $60.00 \mathrm{abc}$ & $60.00 \mathrm{abc}$ & 10,00 \\
J (T. harzianum $)$ & $26.67 \mathrm{e}$ & $26.67 \mathrm{e}$ & $26.67 \mathrm{e}$ & $26.67 \mathrm{e}$ & 60.00 \\
K (Control) & $61.67 \mathrm{ab}$ & $65.00 \mathrm{a}$ & $66.67 \mathrm{a}$ & $66.67 \mathrm{a}$ & 0,00 \\
\hline
\end{tabular}

${ }^{*} \mathrm{C}=$ Carbon fiber, ${ }^{* *} \mathrm{Si}=$ Silica NPs, ${ }^{* * *} \mathrm{DAT}=$ days after treatment.

****Number marked by the same letter within a column are not significantly different according to Duncan's multiple range test at $5 \%$ level.

Silica is easily absorbed by plants and able to protect crops from biotic stresses. Silica in the plant tissue is capable of inducing the formation of polymeric compounds such as lignin and suberin. Polymeric compounds such as lignin and suberin are accumulated into the cell walls that thicken and strengthen the cell walls. Finally, the plant cell wall will be strong and impenetrable by plant pests [19].

Amendment of $T$. harzianum into the soil as an antagonist is able to suppress the development of solborne pathogens and even prevent their infection into the root. Sivan et al. (1987) stated that after administration into the soil, $T$. harzianum would grow and develop, especially around the surface and the tip of the root, so that inhibits the occurrence of exposure and infection by pathogens [20]. T. harzianum is a saprophytic antagonistic fungus to pathogenic fungi by releasing enzymes that may lead to lysis of the pathogen and is mycoparasitic. Alfizar et al. (2011) suggested that T. harzianum, in controlling plant pathogens, produced enzymes $\beta$-(1-3) glucanase and chitinase that resulting in lysis of the cell wall [21]. Aini et al. (2013) added that the antagonism mechanism of T. harzianum against plant pathogens is competition, and mycoparasitism in the soil [22]. This could happen because T. harzianum was able to grow faster on growth media and able to colonize Fusarium oxysporum. All these mechanisms worked synergistically in the soil, thus inhibiting the growth of $F$. oxysporum.

\subsection{Effect of Trichoderma harzianum in Formulation with Carbon Fiber and Silica NPs. on Plant Height}

Application of the formulation of T. harzianum in carbon fiber and silica NPs. also affected the soybean plant height. The treatment has a very significant effect on plant height at 7, 14, 21, and 28 DAT (Table 5). 
Table 5. Effect of T. harzianum in the formulation with carbon fiber and silica NPs. on soybean plant height

\begin{tabular}{lrrrr}
\hline \multirow{2}{*}{\multicolumn{1}{c}{ Treatment }} & \multicolumn{4}{c}{ Plant height (cm) on } \\
\cline { 2 - 5 } & \multicolumn{1}{c}{ 7 DAT } & 14 DAT & 21 DAT & 28 DAT \\
\hline A $($ T. harzianum $+5 \% \mathrm{C})$ & $8.28 \mathrm{de}$ & $18,28 \mathrm{de}$ & $33.03 \mathrm{cde}$ & $54.06 \mathrm{c}$ \\
B $($ T. harzianum $+0.5 \% \mathrm{Si})$ & $14.46 \mathrm{a}$ & $24.97 \mathrm{a}$ & $36.68 \mathrm{a}$ & $62.02 \mathrm{a}$ \\
$\mathrm{C}($ T. harzianum $+1 \% \mathrm{Si})$ & $12.13 \mathrm{~b}$ & $24.17 \mathrm{ab}$ & $35.69 \mathrm{ab}$ & $56.69 \mathrm{~b}$ \\
$\mathrm{D}($ T. harzianum $+3 \% \mathrm{Si})$ & $11.74 \mathrm{~b}$ & $21.85 \mathrm{c}$ & $32.28 \mathrm{de}$ & $53.23 \mathrm{c}$ \\
E $($ T. harzianum $+5 \% \mathrm{Si})$ & $10.46 \mathrm{bc}$ & $22.97 \mathrm{bc}$ & $34.16 \mathrm{bcd}$ & $53.63 \mathrm{c}$ \\
F $($ T. harzianum $+0.5 \% \mathrm{Si}+5 \% \mathrm{C})$ & $10.53 \mathrm{bc}$ & $18.60 \mathrm{~d}$ & $31,00 \mathrm{e}$ & $48.32 \mathrm{e}$ \\
G $($ T. harzianum $+1 \% \mathrm{Si}+5 \% \mathrm{C})$ & $9.46 \mathrm{~cd}$ & $23.10 \mathrm{bc}$ & $34.55 \mathrm{abc}$ & $56.60 \mathrm{~b}$ \\
H $($ T. harzianum $+3 \% \mathrm{Si}+5 \% \mathrm{C})$ & $11.21 \mathrm{bc}$ & $19.49 \mathrm{~d}$ & $32.92 \mathrm{cde}$ & $52.49 \mathrm{~cd}$ \\
I (T. harzianum $+5 \% 5 \% \mathrm{Si}+\mathrm{C})$ & $8.35 \mathrm{~d}$ & $21.77 \mathrm{c}$ & $33.74 \mathrm{bcd}$ & $53.54 \mathrm{c}$ \\
J (T. harzianum $)$ & $12.18 \mathrm{~b}$ & $24.51 \mathrm{ab}$ & $36.56 \mathrm{a}$ & $62.02 \mathrm{a}$ \\
K (Control) & $7,05 \mathrm{de}$ & $16.72 \mathrm{e}$ & $32.53 \mathrm{cde}$ & $50.76 \mathrm{~d}$ \\
\hline
\end{tabular}

$\mathrm{Si}=$ Silica NPs, C = carbon fiber. Number marked by the same letter within a column are not significantly different according to Duncan's multiple range test at $5 \%$ level.

The results showed that treatment B (T. harzianum + silica NPs. 0.5\%) had the highest plant height of $14.46,24.97,36.68$ and $62.02 \mathrm{~cm}$ on $7,14,21$ and 28 DAT respectively, which was not statistically significantly different with treatment E (T. harzianum) on 14, 21 and 28 DAT were respectively 24.51, 36.56 and $62.02 \mathrm{~cm}$. Lowest plant height on 7 and 14 DAT occurred on the control treatment, which was $7.05 \mathrm{~cm}$ and $16.72 \mathrm{~cm}$, respectively. On 21 and 28 DAT the plant height were lowest on treatment F (T. harzianum $+0.5 \% \mathrm{Si}+5 \% \mathrm{C}$ ) i.e. 31 and $48.32 \mathrm{~cm}$ respectively, and control respectively 32.53 and 50.76 $\mathrm{cm}$.

Application of T. harzianum and silica NPs. increased the plant height. This shows that silica is a beneficial element for plants. Silica is in bond with other compounds, so only a small portion can be dissolved and available for plants. The flow of Silica elements in the soil through water media in the form of soil solution [23]. Silica has been widely used to reduce abiotic stress and improve crop resistance to biotic agents. In addition, silica can also stimulate the process of photosynthesis and translocation of carbon dioxide $\left(\mathrm{CO}_{2}\right)$. This is because silica is able to strengthen plant tissue and increase plant resistance to drought by strengthening plant growth through increasing photosynthesis and root activity [23].

\subsection{Effect of Trichoderma harzianum in Formulation of Carbon Fiber and Silica NPs. on Leaf Number}

Application of T. harzianum and silica NPs also affects the number of leaves of soybean plants. On 7 DAT and 28 DAT the treatment did not significantly affect and at the age of 14 DAT and 21 DAT the treatment had a significant effect number of leaves (Table 6).

The results showed that treatment B (T. harzianum $+0.5 \% \mathrm{Si})$ led to the highest number of leaves on 7, 14, and 28 DAT i.e 1.54, 6.57 and 15.17, respectively. However, on 28 DAT the number of leaves on treatment B $(T$. harzianum $+0.5 \% \mathrm{Si})$ was not significantly different with treatment $\mathrm{C}(T$. harzianum + 1\% Si), E (T. harzianum + 5\% Si), G (T. harzianum + 1\% Si + 5\% C), H (T. harzianum + 3\% Si + 5\% C), I (T. harzianum $+5 \% \mathrm{Si}+5 \% \mathrm{C})$ and $\mathrm{J}(\mathrm{T}$. harzianum $+5 \% \mathrm{Si}+5 \% \mathrm{C})$. The lowest number of leaves on 14 and 21 DAT on control treatment, respectively are 4.22 and 8.16, whereas at age 28 DAT lowest number of leaves occur on $\mathrm{F}$ treatment ( $\mathrm{T}$. harzianum $+0.5 \% \mathrm{Si}+5 \% \mathrm{C}$ ) is as much as 13.27 . The addition of silica NPs. in the formulation was able to increase the number of leaves compared to control. It is because the addition of silica nano in plants more easily absorbed by tissues that plant healthier. Deficiency of micronutrients and beneficial nutrients optimum silica can reduce crop productivity. Although micronutrients are needed by plants in small amount, but they are significant in supporting crop production systems. Silica has long been reported as an essential nutrient for some crops (Epstein, 1999). Silica is known as a beneficial element for rice [24]. Although the requirements as beneficial elements are not fulfilled, this element has long been known to be absorbed in large quantities of plants, especially silica accumulator plants are the member of Gramineae and Cyperaceae [25]. 
Table 6. Effect of T. harzianum in the formulation with carbon fiber and silica NPs. on soybean leaf number

\begin{tabular}{|c|c|c|c|c|}
\hline \multirow{2}{*}{ Treatment } & \multicolumn{4}{|c|}{ Number of leaves on } \\
\hline & 7 DAT & 14 DAT & 21 DAT & 28 DAT \\
\hline A $($ T. harzianum $+5 \%$ C) & $1.34 \mathrm{ab}$ & $5.47 \mathrm{abc}$ & $8.19 \mathrm{c}$ & $13.35 \mathrm{~b}$ \\
\hline $\mathrm{B}(T$. harzianum $+0.5 \% \mathrm{Si})$ & $1.54 \mathrm{a}$ & $6.57 \mathrm{a}$ & $10.51 \mathrm{a}$ & $15.17 \mathrm{a}$ \\
\hline $\mathrm{C}($ T. harzianum $+1 \% \mathrm{Si})$ & $1.19 \mathrm{ab}$ & $6.10 \mathrm{ab}$ & $10.02 \mathrm{ab}$ & $14.54 \mathrm{ab}$ \\
\hline $\mathrm{D}($ T. harzianum $+3 \% \mathrm{Si})$ & $1.39 \mathrm{ab}$ & $6.36 \mathrm{a}$ & $9.81 \mathrm{ab}$ & $13.54 \mathrm{~b}$ \\
\hline $\mathrm{E}($ T. harzianum $+5 \% \mathrm{Si})$ & $1.32 \mathrm{ab}$ & $5.31 \mathrm{abc}$ & $9.16 \mathrm{abc}$ & $13.71 \mathrm{ab}$ \\
\hline $\mathrm{F}($ T. harzianum $+0.5 \% \mathrm{Si}+5 \% \mathrm{C})$ & $1.38 \mathrm{ab}$ & $4.85 \mathrm{bc}$ & $8.86 \mathrm{bc}$ & $13.27 \mathrm{~b}$ \\
\hline $\mathrm{G}($ T. harzianum $+1 \% \mathrm{Si}+5 \% \mathrm{C})$ & $1.10 \mathrm{~b}$ & $6.21 \mathrm{ab}$ & $9.94 \mathrm{ab}$ & $14.11 \mathrm{ab}$ \\
\hline $\mathrm{H}(\mathrm{T}$. harzianum $+3 \% \mathrm{Si}+5 \% \mathrm{C})$ & $1.29 \mathrm{ab}$ & $4.83 \mathrm{bc}$ & $8.67 \mathrm{bc}$ & $14.12 \mathrm{ab}$ \\
\hline I (T. harzianum + 5\% 5\% Si + C) & $1.67 \mathrm{ab}$ & $5.27 \mathrm{abc}$ & $8.64 \mathrm{bc}$ & $14.37 \mathrm{ab}$ \\
\hline J (T. harzianum) & $1.47 \mathrm{ab}$ & $6,15 \mathrm{ab}$ & $10.67 \mathrm{a}$ & $14.57 \mathrm{ab}$ \\
\hline $\mathrm{K}$ (Control) & $1.27 \mathrm{ab}$ & $4,22 \mathrm{c}$ & $8,17 \mathrm{c}$ & $13.37 \mathrm{~b}$ \\
\hline
\end{tabular}

$\mathrm{Si}=$ Silica NPs, $\mathrm{C}=$ carbon fiber. Number marked by the same letter within a column are not significantly different according to Duncan's multiple range test at $5 \%$ level.

\subsection{Colonization of T. harzianum in Soybean Planting Medium}

The application of the formulation of T. harzianum in carbon fiber and silica NPs significantly affected the colonization of soybean soil media (Table 7).

Table 7. Colonization of T. harzianum on soybean planting medium.

\begin{tabular}{|c|c|}
\hline Treatment & $\begin{array}{c}\text { Number of } T \text {. harzianum } \\
\text { colonies (cfu / ml) }\end{array}$ \\
\hline A $(T$. harzianum $+5 \% C)$ & $5.20 \times 10^{2} \mathrm{a}$ \\
\hline B (T. harzianum $+0.5 \% \mathrm{Si})$ & $4.64 \times 10^{2} \mathrm{a}$ \\
\hline $\mathrm{C}($ T. harzianum $+1 \% \mathrm{Si})$ & $3.67 \times 10^{2} \mathrm{~b}$ \\
\hline $\mathrm{D}(T$. harzianum $+3 \% \mathrm{Si})$ & $2.28 \times 10^{2} \mathrm{~d}$ \\
\hline $\mathrm{E}(T$. harzianum $+5 \% \mathrm{Si})$ & $3.39 \times 10^{2} \mathrm{bc}$ \\
\hline $\mathrm{F}(T$. harzianum $+0.5 \% \mathrm{Si}+5 \% \mathrm{C})$ & $3.40 \times 10^{2} \mathrm{bc}$ \\
\hline $\mathrm{G}(T$. harzianum $+1 \% \mathrm{Si}+5 \% \mathrm{C})$ & $3.65 \times 10^{2} \mathrm{bc}$ \\
\hline $\mathrm{H}(\mathrm{T}$. harzianum $+3 \% \mathrm{Si}+5 \% \mathrm{C})$ & $2,84 \times 10^{2} \mathrm{~cd}$ \\
\hline I (T. harzianum + 5\% Si + 5\% C) & $3.13 \times 10^{2} \mathrm{bc}$ \\
\hline J (T. harzianum) & $5.25 \times 10^{2} \mathrm{a}$ \\
\hline $\mathrm{K}$ (Control) & $0 \mathrm{e}$ \\
\hline
\end{tabular}

The results showed that treatment $\mathrm{J}$ (T. harzianum) generated the highest number of colonies of $5.25 \times 10^{2} \mathrm{cfu} / \mathrm{ml}$ which was not significantly different with treatment $\mathrm{A}(T$. harzianum $+5 \% \mathrm{C})$ and B (T. harzianum $+0.5 \% \mathrm{Si}$ ), $5.20 \times 10^{2}$ and $4.64 \times 10^{2} \mathrm{cfu} / \mathrm{mL}$, respectively. According to Ellanvihara (2005), the increase in microbial population can be caused by microbes synthesize substances that are contained in a carrier that can trigger microbial growth by removing the cell metabolites [26]. The optimum 
microbial growth can also due to a substrate in a carrier is capable of supporting microbial population. This is consistent with the report of Djaya et al. (2017) that the viability of Pseudomonas fluorescence can be maintained in the addition of 80 mesh carbon fiber $(0.117 \mathrm{~mm})$ at $5 \%$ [15].

The results of this colonization test are directly proportional to the results of the in vivo antagonism test in the formulations T. harzianum which is the best treatment of other treatments that can inhibit the development of disease on soybean damping-off by $60 \%$.

\subsection{Surface Contact Angle on Soybean Seeds}

Calculation of the contact angle using the application Image J with plugins Contac Angle to determine two first point that limits the droplet with the surface of the preparations, and added five points surrounding the droplet as limiting the droplet, then the application ImageJ will automatically calculate the angle $\theta$ left and right of the droplets formed by the surface preparations.

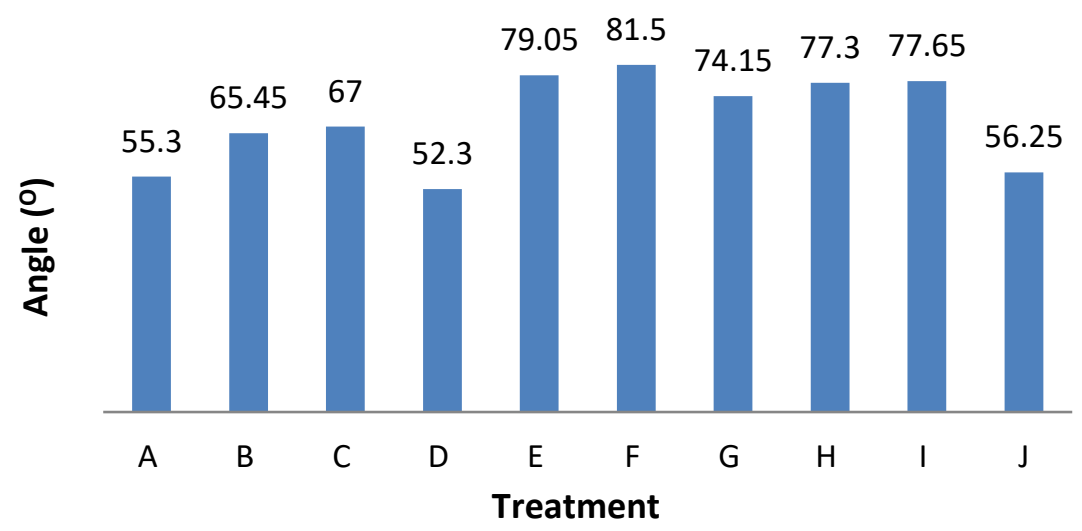

Figure 2. Graph of contact angle on soybean seed. A (T. harzianum + 5\% C), B (T. harzianum + $0.5 \% \mathrm{Si}), \mathrm{C}(T$. harzianum $+1 \% \mathrm{Si}), \mathrm{D}($ T. harzianum $+3 \% \mathrm{Si}), \mathrm{E}($ T. harzianum $+5 \% \mathrm{Si}), \mathrm{F}(T$. harzianum $+0.5 \% \mathrm{Si}+5 \% \mathrm{C}), \mathrm{G}($ T. harzianum $+1 \% \mathrm{Si}+5 \% \mathrm{C}), \mathrm{H}($ T. harzianum $+3 \% \mathrm{Si}+5 \%$ C), I (T. harzianum $+5 \% \mathrm{Si}+5 \% \mathrm{C})$, and J (T.harzianum).

Figure 2. shows that treatment D (T. harzianum $+3 \% \mathrm{Si})$ and $\mathrm{A}($ T. harzianum $+5 \% \mathrm{C})$ is the best treatment in the ability to stick to the seed surface respectively by $52.3^{\circ}$ and $55.3^{\circ}$. Treatment $\mathrm{F}(T$. harzianum $+0.5 \% \mathrm{Si}+5 \% \mathrm{C})$ and $\mathrm{E}(\mathrm{T}$. harzianum $+5 \% \mathrm{Si})$ showed the lowest abilities to attach to the seeds, $83^{\circ}$ and $79.05^{\circ}$ respectively. The lower the slope, the better the abilities of the formulation to stick to the soybean seeds.

\section{Conclusions}

Based on the results, it can be concluded that $T$. harzianum in the formulation of carbon fiber and silica NPs was able to suppress the in vitro growth of Sclerotium rolfsii by 58.76 to $69.84 \%$ and control damping-off on soybean by 7.50 to $37.50 \%$. Single treatment of $T$. harzianum was the best treatment in suppressing the in vitro growth of $S$. rolfsii (80.92\%) and controlling damping-off on soybean seedling $(60 \%)$. Adding of $1 \%$ silica NPs. in the formulation was the best concentration in suppressing the in vitro growth of S. rolfsii with $71.53 \%$ suppression, and controlling damping-off on soybean seedlings by 37.50 $\%$. 


\section{References}

1. Semangun, H.; Penyakit-penyakit Tanaman Pangan di Indonesia; Publsiher: Gadjah Mada University Press; Yogyakarta; 449p, ISBN 979-420-192-8.

2. Sastrahidayat, I. R.; Djauhari, S.; Saleh, N., and Hardiningsih, N.; Pemanfaatan Teknologi Pellet Mengandung Saproba Antagonis dan Endomikoriza (VAM) Untuk Mengendalikan Penyakit Rebah Semai (Sclerotium rolfsii) dan Meningkatkan Produksi Kedelai in Ringkasan Eksekutif Hasil-Hasil Penelitian Tahun 2007; Publisher: Kerjasama Kemitraan Penelitian Pertanian dengan Perguruan Tinggi (KKP3T);Jakarta, 2007; pp. 54-55.

3. Cook, R. J., and Baker, K. F.; Biological control of plant pathogen; Publisher: The American Phytopathological Society, St. Paul, Minnsota, 1983; 433 p.

4. Mohiddin, F. A.; Khan, M. R.; Khan, S. M.; and Hussain, B. Why Trichoderma is considered super hero (super fungus) against the evil parasites. Plant Pathol. J. 2010, 9, 92-102, DOI: 10.3923/ppj.2010.92.102.

5. Widyastuti, S. M.; Sumardi, S.; Sulthoni, A.; and Harjono, H. Pengendalian hayati penyakit akar merah pada akasia dengan Trichoderma spp. J. Perlind. Tan. Indon. 1998, 4(2), pp. 65-72, DOI: 10.22146/jpti.9901.

6. El-Hasan, S.A.; and S.R. Gowen. Formulation and delivery of the bacterial antagonist Basillus subtilis for management of lentil Vascular Wilt caused by Fusarium oxyporum f. sp. Lentis. J. phytopathology 2006, 154(2), pp. 148-155, DOI:10.1111/j.1439-0434.2006.01075.x.

7. Ardianto. Studi karakteristik komposit karbon batu bara/arang batok kelapa berukuran 250 mesh dengan matriks coal tar pitch, Undergraduate Thesis, Fakultas Teknik, Program Studi Teknik Metalurgi dan Material, Universitas Indonesia, Depok, 2011, pp. 7-10.

8. Joni, I M. (Universitas Padjadjaran, Bandung, West Java, Indonesia); Personal communication, 2016.

9. Dendan B. Uji Antagonisme Trichoderma spp. terhadap Ganoderma sp. yang menyerang tanaman sengon secara IN-VITRO. Wallacea J. For. Res. 2015, 4(2), pp. 147-156, DOI: 10.18330/iwallacea.2015.vol4iss2pp147-156.

10. Chet, I.; Henis, Y.; and Kislev, N. Ultra structure of Sclerotia and Hypae of Sclerotium rolfsii Sacc. Microbiology 1969 57(1), pp.143-147, DOI:10.1099/00221287-57-2-143.

11. Howell, C.R. Mechanisms emplyoded by trichoderma spesies in the biological control of plant diseases: the history and evolution of current concepts. plant dis. 2003, 87, pp. 4-10, DOI:10.1094/PDIS.2003.87.1.4.

12. Fadillah, S.; Djaya, L.; Hersanti; and Joni, I.M.; Viability of Pseudomonas fluoresens in nano silica and carbon fiber formulation, Proceeding of the $5^{\text {th }}$ Asian PGPR Internasional Conference for Sustainable Agriculture, Bogor, 2017, pp. 143-144.

13. Rismaniar S., Viabilitas Bakteri Bacillus subtilis PGPR dalam Formulasi Serat Karbon 80 Mesh dan Nano Silika serta Kemampuannya Menekan Pertumbuhan Ralstonia solanacearum secara in vitro, Undergraduate Thesis, Universitas Padjadjaran, Bandung, 2017.

14. Hadisudarmo, P.; Biologi Tanah: Kajian Pengelolaan Tanah Berwawasan Lingkungan, Publisher: Galang Press, Yogyakarta, 2009.

15. Djaya, L.; Hersanti; and Joni, I.M.; Viability of Pseudomonas fluoresens in nano titanium and carbon fiber formulation and its ability to control Ralstonia Solanasearum under in vitro Conditions, Proceeding of the $5^{\text {th }}$ Asian PGPR Internasional Conference for Sustainable Agriculture. Bogor, 2017, p137.

16. Benitez, T; Rincon, A.; Limon, M.C.; and Codon, A.C. Biocontrol mechanisms of Trichoderma strains. Int. Microbiol. 2004, 7(4), pp. 249-260, DOI:10.2436/im.v7i4.9480.

17. Singh, V; Singh, P.; Yadav, R.L.; Awasthi S.K.; Joshi, B.B.; Singh, R.K.; Lal, R.J.; and Duttamajumder, S.K. Increasing the efficacy of Trichoderma harzianum for nutrient uptake and control of red rot in sugarcane. J. Hort. For. 2010, 2(4), pp. 66-71.

18. Yuliani, K.; Ngadiwiyana; Siswoyo, E.; Amaliah, D. A.; Wahyono, Y.; and Widianingrum. D. Pengaruh kombinasi silika dan kitosan berbasis nanoteknologi sebagai bahan dasar pembuatan pupuk nano slow release terhadap penyerapan unsur hara oleh tanamandalam meningkatkan hasil pertanian di Indonesia. Artikel Ilmiah Teknologi Kimia dan Industri, Universitas Diponegoro. Semarang 2015.

19. Dewi, Y. A.; Putra, E. T. S. P.; and Trisnowati, S. Induksi Ketahanan Delapan Hibrida Kelapa Sawit (Elaeis guineensis JACQ.) dengan Silika. Vegetalika 2014, 3(3), pp. 1-13. DOI:10.22146/veg.5154. 
20. Sivan, A.; Ucko, 0; and Chet, I. Biological control of Fusarium crown rot of tomato by Trichoderma harzianum under field conditions. Plant Disease 1987, 71, pp. 587-592, DOI:10.1094/PD-71-0587.

21. Alfizar; Marlina; and Hasanah, N. Upaya Pengendalian Penyakit Layu Fusarium oxysporum dengan Pemanfaatan Agen Hayati Cendawan FMA dan Trichoderma harzianum . Universitas Syiah Kuala Darussalam Banda Aceh. J. Floratek 2011, 6, pp. 8-17.

22. Aini, F. N.; Sukamto, S.; Wahyuni, D.; Suhesti, R. G.; and Ayunin, Q. Penghambatan pertumbuhan Colletotrichum gloeosporioides oleh Trichoderma harzianum, Trichoderma koningii, Bacillus subtilis dan Pseudomonas fluorescens. Pelita Perkebunan 2013, 29(1), pp. 44-52.

23. Djajadi. Silika (Si): unsur hara penting dan menguntungkan bagi tanaman tebu (Saccharum officinarum L.). Perspektif 2013, 12 (1), pp. 47-55.

24. Epstein, E. Silicon. Annu. Rev. Plant. Physiol. Plant. Mol. Biol. 1999, 50, pp. 641-664. DOI:10.1146/annurev.arplant.50.1.641.

25. Ma, J. F.; and Takahashi E. Soil, Fertilizer, and Plant Silicon Research in Japan; Publisher: Elsevier, Amsterdam, 2002, 294p, ISBN: 9780080525761.

26. Ellanvihara, M. Pertumbuhan dan Aktivitas Eksoprotease Bacilus licheniformis dan Bacillus mengaterium di Medium Ekstrak Limbah Padat udang. Undergraduate Thesis, Department of Biology, FMIPA Universitas Sebelas Maret Surakarta, 2005. 